\title{
Effects of dietary fatty acids on gene expression and biological processes in different tissues of pigs: A Review
}

Simara Larissa Fanalli 1, Bruna Pereira Martins da Silva 1, Bruna Petry ${ }^{2}$, Miguel Henrique de Almeida Santana ${ }^{1}$ Guilherme Henrique Gebim Polizel 1, Robson Carlos Antunes ${ }^{3}$, Vivian Vezzoni de Almeida ${ }^{4}$, Gabriel Costa Monteiro Moreira 5, Albino Luchiari Filho ${ }^{2}$, Luiz Lehmann Coutinho ${ }^{2}$, Júlio Cesar de Carvalho Balieiro ${ }^{6}$, James Mark Reecy 7, James Koltes 7, Dawn Koltes 7, Aline Silva Mello Cesar 1, 2*

1 Faculty of Animal Science and Food Engineering, University of São Paulo, Campus Fernando Costa, Avenue Duque de Caxias Norte 225, 13635-900, Pirassununga, São Paulo, Brazil; simarafanalli@usp.br; brunamartins@usp.br; mhasantana@usp.br; guilherme.polizel@usp.br

2 Luiz de Queiroz College of Agriculture, University of São Paulo, Avenue Pádua Dias 11, 13418-900, Piracicaba, São Paulo, Brazil; alinecesar@usp.br; bruna.petry@usp.br; luchiari@usp.br; llcoutinho@usp.br

3 College of Veterinary Medicine, Federal University of Uberlândia, Campus Umuarama, Avenue Pará 1720, Bloco 2T, 38400902, Uberlândia, Minas Gerais, Brazil; robson.antunes@ufu.br

4 Federal University of Goiás, College of Veterinary Medicine and Animal Science, Department of Animal Science, Highway Goiânia - Nova Veneza, km 8, Campus Samambaia, 74690-900, Goiânia, Goiás, Brazil; vivian.almeida@ufg.br

5 University of Liège, GIGA Medical Genomics, Unit of Animal Genomics, Quartier Hôpital, Avenue de l'Hôpital, 11, 4000, Liège, Belgium; gcmmoreira@gmail.com

6 College of Veterinary Medicine and Animal Science, University of São Paulo (FMVZ/USP), Av. Duque de Caxias Norte, 225, 13.635-900, Pirassununga, São Paulo, Brazil; balieiro@usp.br

7 Iowa State University, College of Agriculture and Life Sciences, Department of Animal Science, 1221, Kildee Hall, 50011-3150, Ames, Iowa, USA; jreecy@iastate.edu; delkins@iastate.edu; jekoltes@iastate.edu

* Correspondence: alinecesar@usp.br

Simple Summary: Fatty acids are one of the basic building blocks of lipids. They have a fundamental role in structural and biological functions, e.g. they are an important component of the cell membrane. Studies on the influence of these compounds and their effects on organisms are of great importance. The use of fatty acids in the diet of pigs, an animal model for metabolic diseases that affect humans, brings great advances in several areas and its results have been significant in transcriptomic and nutrigenomic studies. Thus, the objective of this review was to bring together the knowledge about the effects of dietary fatty acids in pigs on biological processes, on product on traits and gene expression.

\begin{abstract}
Studies on the influence of dietary components and their effects are fundamental for nutrigenomics, or the study of how nutrients can be cellular sensors, how they affect biological processes and gene expression in different tissues. Lipids are an important source of fatty acids (FA) and energy and are fundamental to biological processes and influence the regulation of transcription. Pigs are excellent model to study nutrigenomics, particularly lipid metabolism because the deposition and composition of FA in their tissues reflect the composition of FA in their diet. Recent studies show that FA supplementation is important in production systems, such as growing and finishing pigs, as it can improve the energy value of the feed, help reduce costs, improve animal welfare, and influence the nutritional value of the meat. Studies show that oleic (OA), linoleic (LA), docosahexaenoic (DHA), and eicosapentaenoic (EPA) acids are associated with the regulation of transcription in tissues such as muscle, liver, adipose tissue, and brain. Other studies indicate that EPA and DHA are associated with changes in specific signaling pathways, altering gene expression and biophysical properties of membranes. This review, therefore, focuses on the current knowledge of the effects of dietary FA on production traits and gene expression.
\end{abstract}

Keywords: animal model; dietary components; feeding strategy; gene expression; lipid profile; nutrients; nutrigenomic; physiological processes; signaling pathways; transcription. 


\section{Introduction}

According to the World Population Review [1], about 219,000 people are added to the world population each day. Taken together with the limited natural resources on the planet, there is a real need to identify new food production strategies in agriculture that increase the efficiency of food production [2]. The expected increase in food consumption will likely raise the demand for meat consumption from 200 million to 470 million tons per year, requiring an increase of $70 \%$ in production efficiency by the year 2050 [3]. In addition to the search for greater efficiency in food production, nutrition quality is a decisive factor for consumer choice. The nutritional quality of pork is an important characteristic that influences the health of consumers as pork is the second most consumed source of animal protein worldwide, accounting for about $34 \%$ of total consumption, with poultry in first with $39 \%$, beef with $20 \%$ in third, and sheep meat with $5 \%$ in fourth position [3]. In swine production, specific nutrients in the diet, such as fats, are of fundamental importance in pork quality [4]. Supplementing the diet of pigs with oils of different sources and levels may modulate the fatty acids (FA) composition of pork. In addition, because pigs are monogastric animals, it is easier to change the FA profile of pork fat [5]. The effects on fat processing qualities are of great importance, and the AF profiles are closely related to meat characteristics. Pigs fed a high oil content of ground corn had the highest vertical and lowest lateral flex, and they tended to have the highest yield at cutting, but a softer belly did not result in poorer sliceability in the study of Rentfrow et al., [6].

With technological advances, molecular animal nutrition stands out as a field of study that combines animal nutrition with molecular biology at its basic level [7]. This branch studies the biological processes involved at the level of gene expression and nutrient-gene interaction with the help of modern molecular biology techniques and technologies [8]. Following the advance of molecular biology, the omics sciences, including genomics, transcriptomics, proteomics, and metabolomics, provide the tools to unravel the molecular mechanisms involved in phenotypes of interest. Thus, more specifically, nutrigenomics studies the impact of dietary constituent on the transcriptome, proteome, and metabolome of an animal. These approaches combine high-throughput sequencing technologies and/or mass spectrometry with dietary components and seek to understand how a nutrient may affect gene, protein, and metabolite abundance. These types of studies can elucidate the basic molecular mechanisms in which nutrients may be interacting to regulate gene expression, physiological processes, cell biochemical responses, as well as the expression of the phenotype [9].

The objectives of this review were: (1) to highlight the role of dietary FA in pigs and their impact on characteristics of production and biological interest; (2) to describe the molecular effects of FA along the entire pig production chain; and (3) to report the impact of FA on the liver, skeletal muscle, and brain in this animal species.

\section{Pig Farming: Animal Characteristics, Pork Consumption and Consumer Prefer- ences and Pork Production Strategies that Support these Preferences}

Animal Characteristics: The domestic pigs belong to the species Sus scrofa. Pigs are considered ideal animal models as they share anatomical, morphological, physiological, 
and metabolic similarities with humans [10], [11]. Moreover, pigs possess high homology and chromosome structure with the human genome compared to other animal species [12]. Also, they are used as animal models for metabolic diseases research in humans [10], [13]-[15]. When the genomes of 48 individual pigs were sequenced, 32,548 nonsynonymous single nucleotide polymorphisms (SNP) were observed, six of which were linked to human diseases and 11 of them were associated with human disease phenotypes [12]. There is also evidence that the pig transcriptome is very similar to that of humans [16]. Therefore, pigs are considered a good animal model and more advanced studies are being conducted involving biological processes of interest and advancing knowledge in areas such as nutrigenomics using new generation technologies [10], [16], [17].

Pork Consumption and Consumer Preferences: Pork meat is among the second most consumed meat in the world, accounting for 33\% of production and $34 \%$ of global meat consumption [18]. According to the Associação Brasileira de Proteina Animal [19], the five largest pork producers in the world are China, the European Union, the United States, Brazil, and Russia. Pork not only has economic importance but also has a nutritional composition to ensure a healthy, balanced, and safe diet for the population [20], [21].

Lean pork has a desirable nutritional profile [21] because its composition is high in protein and low in fat, has a constant ratio of cell membrane phospholipids and has a good quantity of polyunsaturated fatty acids (PUFA) [22]. It also has neutral lipids that consisting mainly of triacylglycerol (TAG), which are rich in saturated fatty acids (SFA) [21]. However, pork has a high ratio of $n-6 / n-3$ due to diets used in swine production. These practices are based on the use of vegetable oils from corn, sunflower, and soybean, which are high in n-6 family PUFA, mainly linoleic acid (LA) [21], [23]. In addition, the genetic selection of pigs designed for lean growth has increased the concentration of LA in pork [22]. However, fat content has a direct effect on flavor and juiciness, as well as on the tenderness and firmness of pork [24]. For example, oleic acid (OA) is the predominant FA in pork tissue (about $40 \%$ ), whereas LA content is highly correlated with fat firmness. Moreover, the amount of LA is inversely correlated with backfat thickness [24].

Feedstuffs enriched with vegetable oils, especially sunflower, soybean, and canola, contain elevated levels of LA, OA, and alpha-linolenic acid (ALA), which are considered unsaturated FA. For this reason, the search for foods with higher PUFA and monounsaturated fatty acids (MUFA) content has increased among consumers, who demand healthier foods with health benefits [20], [25], [26]. Thus, pork meat fortification is a viable strategy to increase consumption of n-3 FA, especially in populations that consume less fish or marine products. It also helps to reduce the consumption of SFA, which can have negative effects on health and when over consumption could increase the risk of developing some diseases [21], [27], [28].

Pork Production Strategies that Support these Preferences: Pigs are monogastric (like humans) and have FA deposition as a reflection of the FA composition of their diet [13]. This may contribute to the knowledge of what happens, for example, to the nutritional value of meat and what biological processes are involved in the metabolism of FA in these animals [29], [30]. Changing feeding strategy is the most widely used management factor in the industry. It is widely used to improve food production, including meat, milk, and eggs. It is also used as a tool for quality control in livestock production, as well as for 
improving the nutritional value of the final product, animal welfare, food safety, technology, and quality [31], [32].

Changes in feeding strategy is used for supplementing the animal diet with specific components to obtain nutritional and health advantages, such as the use of dietary components that contribute to the content and composition of lipids in relation to the nutritional value of meat [22], [32], [33]. An example of this is a study of Øverland et al. [34], where different types and inclusion levels of soybean oil and fish oil were used. An increase in fish oil was associated with an increase in muscle and adipose tissues omega3 (n-3) FA content and a decrease in the ratio omega-6/omega-3 (n-6/n-3). Pigs fed diets containing fish oil until slaughter had an increase in off-flavor and odor intensity of subcutaneous fat. As for soybean oil, it is a highly unsaturated fat source and is commonly used in pig diets [35]. Additionally, a diet rich in fish oil may increase n-3 PUFA content in adipose tissue and muscle [22].

The enrichment of FA in the diet of pigs is important due to the high energy content of the diet while increasing FA content ( 0 to $5 \%$ ) decreases feed intake and increases feed efficiency in growing and finishing pigs [36], [37]. In addition, enrichment of the diet with PUFA, especially from n-3 family, may reduce overall feed consumption, improve energy availability to the animals, modify the FA profile of the final product without reducing the total fat content, and may associate FA with metabolic diseases, thus benefiting animal health [20], [21], [31], [38], [39].

The influence of maternal nutrition on the progeny phenotype has been widely studied in several species. The inclusion of different levels and types of fat in the diet of pregnant sows has already been shown to effect birth weight and neonatal piglet survival, oxidative stress, inflammatory response, cognitive development, number of born piglets, body weight gain, FA composition of sow's milk and plasma, and plasma of their piglets [37], [40]-[43]. Confirmation of the above information has been obtained with lactating sows, which showed increased milk fat concentration and higher piglet weight at weaning [37].

Other benefits of supplementing lipids to the pig diet include reduced wear and tear on feed processing equipment. Moreover, under hot climate conditions, lipid-enriched diets reduced heat gain (digestion and fat metabolism) compared to carbohydrate and protein-enriched diets, as well as increased feed intake and body weight gain [37]. It is worthy to mention that feeding diets that contained supplemental lipids increased palatability and generated less body heat [44]-[47].

\section{Lipids and Fatty Acid Metabolism}

Lipids are a class of molecules found in all cell types; are composed of hydrogen, carbon, and oxygen atoms; and are present in all forms of life [48], [49]. Lipids play a fundamental role in the structure of cell membranes and biological processes from transcriptional regulation to physiological processes [50], [51]. They are hydrophobic in nature and an important source of metabolic energy, they also play a role as a structural matrix, a permeability barrier in membranes, and act as transport of fat-soluble vitamins A, D, E, K [49], [52]-[54]. Due to vast cellular functions, the ability to synthesize a variety 
of lipids is essential; however, not all can be produced by the body and must be acquired from the diet, such as LA and ALA [49], [55].

As part of the complex lipid molecules, FA are the basic structure of lipids such as fats and phospholipids. They are stored in adipose tissue as triacylglycerides, which is the predominant dietary source of FA [49], [54]. They are classified into saturated and unsaturated FA, the second class being MUFA and PUFA [49], [51], [54], [55].

Saturated FA are considered a fundamental source of energy and part of components in cell membranes. In addition, they are categorized as non-essential FA since their synthesis can occurs in all organisms [49], [51]. The most common SFA found in plant and animal tissues are those with a linear chain of 12 to 18 carbons, with palmitic acid (C16:0) being the most abundant and found in most plant oils, in fish oil, and in the body fat of some animals. As examples of SFA, stearic acid (C18:0), myristic acid (C14:0), and lauric acid (C12:0) may be mentioned [49], [51], [54].

Unsaturated FA contain at least one carbon-carbon double bond and may occur in cis- and trans-isomeric forms [49], [51]. The cis-form or Z-configuration is the one found in all biological FA and contains two adjacent carbons on the same side as the double bond carbons. On the other hand, the trans-form or E configuration contains at least one double bond with the two adjacent carbons on opposite sides of the carbon bond [49], [54].

As mentioned earlier, MUFA are monounsaturated FA and are defined as having only one double bond in the aliphatic chain. MUFA, also known as omega-9 (n-9) FA, are synthesized in the human body, and found in olive and canola oils, an important example being OA, which is produced from stearic acid by the enzyme stearoyl-CoA desaturase [22], [49]. Recently, MUFA have been attributed health benefits, such as the prevention of cardiovascular disease [49], [56], as they reduce low-density lipoprotein (LDL) and increase high-density lipoprotein (HDL). They are also associated with a lower likelihood of a cognitive decline in the elderly, reduction in breast and ovarian cancer rates, and are important for the structure of the cell membrane of the myelin sheath of nervous tissue [49], [51]. In addition, OA plays an important role in several cellular processes related to cell growth, oxidative phosphorylation, migration, cell growth, and survival [57].

The PUFA are unsaturated FA that contain two or more double bonds in their aliphatic chain, the most important being LA (C18:2 n-6), ALA (C18:3 n-3), arachidonic acid (AA, C20:3 n-6), docosahexaenoic acid (DHA, C22:6 n-3) and eicosapentaenoic acid (EPA, C20:5 n-3), while LA, AA, and ALA are essential FA and precursors to other FA. The ALA is found in canola, soybean, and flaxseed oils, as well as nuts and meats, whereas EPA and DHA are found in seafood, mainly oily fish [25], [26], [49], [58], [59]. AA is one of the most abundant FA and is present in all biological membranes, moreover, it can account for 5 to $15 \%$ of the total FA in most tissue phospholipids [60].

Polyunsaturated FA have PUFA n-3 and PUFA n- 6 as important families. The n-3 family can be divided into short-chain PUFA such as ALA and long-chain (LC), EPA, DHA, and docosapentaenoic acid (DPA, C:22:5 n-3) [25], [59], [61]. The PUFA of the n-3 family, ALA, EPA, and DHA are the three most important FA in human physiology, moreover, the intake of these FA may be related to the reduction in the risk of stroke and coronary heart disease [26], [49], [62]. In addition, ALA is more common in its category, especially in diets that do not regularly include fatty fish and do not involve 
supplementation [26], [53], [61]. EPA and DHA FA may be ingested from the diet or synthesized by the body from LA and ALA. Conversely, n-6 PUFA are involved in the regulation of the synthesis of eicosanoids (molecules derived from C:20 FA of the n-3 and n-6 families), which control the activity of the immune system [16].

Mammals generally do not have the fundamental enzymes to insert the double bond at the $n-3$ and n- 6 positions. Therefore, LA and ALA and some derivatives, which are also considered essential, depend solely on food, and their absence or intake in reduced amounts may cause a general deficiency syndrome in the body or parts of it [25], [63]. This deficiency may result in some symptoms such as fatigue, immunological problems, issues related to the cardiovascular system, as well as growth retardation, and neurological diseases, these include attention deficit hyperactivity disorder (ADHD), depression, in addition to Alzheimer's disease [55], [58].

In general, the metabolism of FA and TAG is regulated by transcriptional and posttranscriptional mechanisms [29]. Digestion of dietary TAG occurs in the intestine, where they are hydrolyzed to FA and monoglycerides and absorbed by enterocytes. After hydrolysis, FA are re-esterified to TAG and secreted into the bloodstream as part of the chylomicrons [29]. The chylomicrons that are in the plasma undergo rapid lipolytic processing by the action of lipoprotein lipase (LPL), which results in the release of FA into the tissues. The rate of absorption in individual tissues varies regardless of the specific delivery pathway and is influenced by factors such as the metabolic activity of the tissues, food intake and nutritional status, intake of fat and other nutrients such as carbohydrates [29], [64]. In addition, metabolic disturbances may affect the flow of free fatty acids (FFA) and TAG derived FA [29].

For cellular uptake of FFA, there are several proteins, such as CD36, and several transporters and after uptake, FA are bound by proteins and can have several metabolic fates. According to Georgiadi and Kersten [29], there is evidence that FA also has the property of being signaling molecules, which is in part due to regulation of gene transcription. Conjugated linoleic acid (CLA) plays a fundamental role in lipid metabolism, particularly in the cellular oxidative system, thereby is considered an important nutrient for human nutrition, although it is only synthesized in ruminants, and may contribute to the control of diseases such as obesity [33], [65] and in pigs, they may have antitumor and immune-enhancing properties [66].

Many proteins are involved with the LC FA, among them plasma membrane fatty acids binding protein (FABPpm), fatty acids translocase (FAT), caveolin-1, and very-longchain acyl-CoA synthetases (ACSVL), that are FA transport proteins, which may also be referred to as FATP/Solute Carrier Family 27A1-6, SLC27A1-6 [67], [68]. Proteins, such as FABPpm, play an important role in FA uptake in the heart and skeletal muscle, but their role in hepatocytes is not clearly understood [69].

The Peroxisome Proliferator-Activated Receptors (PPAR) are the best-known sensing system for FA. In addition to transcription factors that belong to the nuclear hormone receptor family, are activated by a ligand, and bind to small lipophilic molecules. They play a role in several biological processes and have a modular structure that has a DNAbinding domain and a ligand. The FA, derivatives, or compounds that have a similar structure to acyl-CoA and oxidized FA, may activate PPAR [70]-[73]. In terms of beneficial 
effects, studies have shown evidence of the interaction of PUFA with nuclear receptors. In addition to influencing gene expression, it regulates the activities of transcription factors, including a sterol regulatory element-binding protein (SREBP), PPAR, liver $X$ receptor (LXR), and the retinoid X receptor (RXR) [74], [75].

Related to PPAR- $\alpha$, it is involved in the control of hepatic lipid content, as well as the number of lipids for synthesis and secretion of very low-density lipoproteins (VLDL) that induces FA oxidation, whereas SREBP-1c induces FA synthesis [76]. Lipid metabolism studies have become increasingly vital in the context of human metabolic diseases, including obesity, non-alcoholic fatty liver disease (NAFLD), and type 2 diabetes, as well as neurodegenerative diseases and cancer [77].

\section{Lipid and their effects on human health}

Fatty acids like ALA have been attributed to anti-inflammatory, anti-atherosclerotic, and antithrombotic effects, and it is also a precursor of EPA and DHA [61]. In turn, AA is of outstanding importance as it is found in the liver and brain tissues and ensures the normal functioning of these two tissues [58]. The AA is the precursor of important eicosanoids [78]. Moreover, most prostaglandins, a type of substance with high physiological activity like hormones and belonging to the group of eicosanoids, are derived from AA [79]. AA is involved in several functions of the brain, including permeability of physiological membranes, in addition to involvement in local blood flow [55], [79]. The DHA affects cell interactions and enzymatic activity, in addition to influencing some physical properties of brain membranes and the properties of their receptors [55], [80].

Studies show that DHA acts on the physical properties of brain membranes and AA is strongly related to retinal and brain developments. Furthermore, several studies have indicated that these FA are responsible for maintaining brain and retinal functions, from the gestational period to the first years of development [79], [81], [79], [82]. Additionally, a higher intake of PUFA may provide benefits in terms of reducing the risk of cardiovascular disease, due to a reduction in LDL, in the same way as MUFA. Thus, several studies have been conducted and consumer interest in these compounds is growing because they can modify some properties such as food safety, nutritional value, composition, and lipid content, in addition to acting on oxidative stability, preventing disease, and improving the fatty acid profile of meat [31], [32], [79].

Furthermore, ALA is a metabolic precursor to DHA and EPA [49]. To form the abovementioned FA, numerous reactions occur in the biosynthetic pathway, including reactions that occur in the endoplasmic reticulum such as desaturation and elongation reactions, and beta-oxidation that occur in peroxisomes, with the rate-limiting enzyme of the process converting to a $\Delta 6$ desaturase (D6D) [26]. In the beta-oxidation of ALA, which occurs in mitochondria, carbon units of acetyl-CoA can be formed. These may be recycled and used to synthesize other compounds such as SFA, MUFA, ketone bodies, and cholesterol. Furthermore, EPA and DHA, which are derived from ALA, are present in greater amounts in cells at the end of the ALA metabolic process [26], [83]. 
According to Elmadfa and Kornsteiner [53] and Eshak, Yamagishi, and Iso [51], LA and ALA are fundamental to physiological processes and when they are taken up in insufficient amounts, processes such as inflammation, healing, and blood clotting are impaired. According to the same authors, these processes are fundamental and directly related to prostaglandins and leukotrienes, in addition, LA is a precursor of AA, which is directly involved in gene expression.

Results from epidemiological studies show that there is a positive association between consumption of some FA and long-term health benefits [82]. Very long-chain EPA and DHA are involved in cell membrane viscosity and are associated with reduced mortality related to cardiovascular disease [84]-[86]. They show positive results for visual and neurological development and are important for the prevention of diseases such as Alzheimer's disease [87]-[90]. The EPA and DHA are also associated with changes in specific cell signaling pathways, gene expression, and biophysical properties of cell membranes [29], [91], [92].

The intake and/or synthesis of FA from the n-3 and n-6 families are essential for the body [49]. However, studies have demonstrated that an excess of FA, even when considered beneficial to health, may cause deleterious effects [81]. High concentration of MUFA is associated with obesity, type 2 diabetes, and metabolic syndrome. On the other hand, the essential FA of the n-6 family, together with SFA and when consumed in large amounts, as in the western diet, may pose several health risks and increase the likelihood of developing diseases such as obesity, coronary, and neurodegenerative diseases [25], [55], [93].

As it is of great importance for biological processes, the ingestion and/or synthesis of FA from the $n-3$ and n-6 families are essential for the organism. Studies indicate that an ideal proportion of n- 6 and n-3 PUFA is important to maintain the healthy homeostasis of metabolism and biological processes. The availability of different types of FA, coming from the diet and biological synthesis, may affect this n-3/n-6 ratio, and it determines the availability of energy and FA available for biological processes [49], [81]. This reason may also be affected during the synthesis process as the reactions of the two families occur in the same metabolic pathway, thus generating competition for the desaturation and elongation enzymes during the conversion process [16], [26], [55], [81]. This proportion was discussed and evaluated in each region and country according to the trend in nutrition and availability of source foods. These proposals have been reviewed and generally agreed on the range of 4:1 to 5:1, but some authors recommend a ratio of 2:1 to 3:1, stating that this range allows greater conversion of ALA in DHA [49], [81].

From the excessive consumption of $\mathrm{n}-6$, there may be a prevalence of atherosclerosis, obesity, diabetes, and cancer. Thus, there is interest in diets that use oils rich in MUFA, mainly OA, such as canola oil, and PUFA n-3 as EPA and DHA, found in high concentrations in fish oil. The OA ingestion is associated with vital processes, including oxidative phosphorylation and growth, in addition to cell survival, and adequate levels of EPA and DHA can prevent the risk of atherosclerotic disease [94].

According to Yehuda, Rabinovitz, and Mostofsky [79], diets based on a specific ratio of n-3 and n-6 may have several benefits, such as reducing total cholesterol and increasing PUFA content in the nerve membrane, thereby reducing the risk of coronary and 
neurodegenerative diseases. When this ratio is imbalanced, it can be associated with cardiovascular, inflammatory, autoimmune, and diabetic diseases [95]. Another important point is the need to understand that the effects of a given ratio may be related to several factors, such as changes in FA profile, cholesterol profile, in addition to the availability and dependence of metabolism of FA, which vary in the population [55], [96].

Studies have reported that the consumption of FA can positively or negatively alter a wide range of metabolic pathways associated with chronic diseases. Several studies have demonstrated that OA, LA, DHA, EPA, and CLA may regulate gene transcription in some tissues, including skeletal muscle, adipose tissue, liver, and brain [20], [28], [97], [98]. However, there is still a need for more in-depth studies that can link the intake structure, the biological pathway associated with the disease process. Furthermore, studies must demonstrate ways to quantify the impact of FA, in other words, present knowledge on how the property (signaling molecules) directly affects biological processes of interest [29]. Table 1 provides further details on important fatty acids described in pork.

Table 1. Important fatty acids already described in pork

\begin{tabular}{cl}
\hline Fatty Acids & \multicolumn{1}{c}{ Description } \\
\hline Saturated fatty acids (SFA) & It is used as a food additive and has \\
Lauric Acid (LA) & antimicrobial and immunomodulatory activity \\
& {$[99]$} \\
Palmitic Acid (PA) & Over consumption of saturated fatty acids could \\
& increase risk of diseases [100] \\
\hline
\end{tabular}

Unsaturated fatty acids (UFA)

Polyunsaturated fatty acids

(PUFA)

Linolenic acid (LA)

Correlated with back fat thickness [24]

Fundamental to physiological processes and

Alpha-Linolenic acid (ALA)

when they are taken up in insufficient amounts, processes such as inflammation, healing, and blood clotting [51], [53]

Arachidonic acid (AA)

Is the precursor of important eicosanoids [79] EPA and DHA are also associated with changes in specific cell signaling pathways and alteration

Docosahexaenoic acid (DHA) of gene expression, in addition to changes in the biophysical properties of cell membranes [29], [91], [92]

Conjugated linoleic acid (CLA) In pigs, they may have antitumor and immuneenhancing properties [66]

Monounsaturated fatty acids

(MUFA)

Oleic Acid (AO) Correlated with fat firmness [24] 


\section{Fatty Acids and Muscle}

The FA content in muscle is lower, but its FA composition is like that in adipose tissue. Hence there are differences between the tissues and a significant diversification between the species [22]. Some FA in pork, such as OA, palmitic acid, stearic acid, LA, palmitoleic acid, and tetradecanoic acid, account for $90 \%$ of the total FA present in the Longissimus lumborum muscle. These FA are linked to nutrition and sensory properties of pork [100]. Skeletal muscle is essential for maintaining glycemic control as it is associated with some of the elimination of postprandial glucose, and it is further manipulated by diet composition [101]. Muscle has significant amounts of LC-PUFA through the action of enzymes such as enzyme $\Delta 5$ and D6 desaturase and elongase [22].

Molecular tools allowed to perform different studies that identified: differentially expressed genes (DEG) between a group of animals, with extreme values of FA content in skeletal muscle, and gene networks associated with these traits [68]; and several eQTL (expression Quantitative Trait Loci) combining high-density SNP and RNA sequencing (RNA-seq) [102].

Studies revealed a significant number of DEG in animals with extreme values of FA content in bovine skeletal muscle [28], [102], [103]. These genes have been linked to biological processes, including insulin receptor signaling, nuclear factor of activated $\mathrm{T}$ cells (NFAT), mitochondrial disorders, and neurodegenerative diseases, especially Huntington's and Alzheimer's diseases. However, associated with major changes in expression, only two of the seven classes of FA molecules were studied. Skeletal muscle profile as OA and CLA-c9t11 content. These molecules had significant effects on the expression levels of genes associated with biological processes related to oxidative phosphorylation and cell survival, growth, and migration [69]. Previous studies have shown that the SFA may be linked to some types of diseases, including cardiovascular diseases, obesity, and type 2 diabetes mellitus [104], [105]. In general, meat has a high nutritional value, being considered a valuable source of unsaturated FA, such as OA and LA [106].

Using Large White immunocastrated pigs fed different sources and levels of oil during growing and finishing phases, it was demonstrated that diets that contained 3\% fish oil had higher levels of SFA, EPA, DHA, and PUFA than n-3 in Longissimus lumborum muscle lipids. Dietary treatments containing $1.5 \%$ or $3 \%$ soybean or $3 \%$ fish oil, or even $3 \%$ canola oil altered the FA composition of muscle (Table 2) [94]. 
Table 2. Effects of dietary treatments on fatty acid composition (\%) of Longissimus Lumborum intramuscular fat of growing-finishing pigs ${ }^{1}$

\begin{tabular}{|c|c|c|c|c|c|c|}
\hline \multirow[b]{2}{*}{ Item } & \multicolumn{4}{|c|}{ Dietary treatment } & \multirow{2}{*}{$\begin{array}{l}\text { Pooled } \\
\text { SEM }^{2}\end{array}$} & \multirow{2}{*}{$\begin{array}{c}P- \\
\text { value }\end{array}$} \\
\hline & Control & $\mathrm{SO}$ & $\mathrm{CO}$ & $\mathrm{FO}$ & & \\
\hline \multicolumn{7}{|l|}{ Saturated fatty acid (SFA) } \\
\hline Myristic acid (C14:0) & 1.14 & 1.19 & 1.21 & 1.24 & 0.01 & 0.11 \\
\hline Palmitic acid (C16:0) & $25.50^{\mathrm{b}}$ & $25.01^{\mathrm{b}}$ & $24.70^{\mathrm{b}}$ & $26.43^{\mathrm{a}}$ & 0.21 & $<0.01$ \\
\hline Stearic acid (C18:0) & $12.02^{\mathrm{b}}$ & $11.89^{\mathrm{b}}$ & $11.04^{c}$ & $12.63^{\mathrm{a}}$ & 0.15 & $<0.01$ \\
\hline \multicolumn{7}{|l|}{ Monounsaturated fatty acid (MUFA) } \\
\hline Palmitoleic acid (C16:1) & $2.86^{\mathrm{b}}$ & $3.17^{a}$ & $3.05^{\mathrm{ab}}$ & $3.26^{\mathrm{a}}$ & 0.05 & 0.04 \\
\hline Oleic acid (C18:1 n-9) & $38.92^{\mathrm{b}}$ & $44.60^{\mathrm{a}}$ & $44.95^{\mathrm{a}}$ & $40.33^{b}$ & 0.64 & $<0.01$ \\
\hline Eicosenoic acid (C20:1 n-9) & 0.51 & 0.56 & 0.58 & 0.56 & 0.01 & 0.21 \\
\hline \multicolumn{7}{|l|}{ Polyunsaturated fatty acid (PUFA) } \\
\hline Linoleic acid (C18:2 n-6) & $17.90^{\mathrm{a}}$ & $12.96^{\mathrm{b}}$ & $13.33^{\mathrm{b}}$ & $13.83^{b}$ & 0.50 & $<0.01$ \\
\hline Alpha-linolenic acid (C18:3 n-3) & $0.80^{\mathrm{a}}$ & $0.54^{\mathrm{b}}$ & $0.53^{\mathrm{b}}$ & $0.59^{b}$ & 0.03 & $<0.01$ \\
\hline Eicosapentaenoic acid (C20:5 n-3, EPA) & $0.29 b$ & $0.11^{c}$ & $0.08^{c}$ & $0.46^{\mathrm{a}}$ & 0.04 & $<0.01$ \\
\hline Docosahexaenoic acid (C22:6 n-3, DHA) & $0.36^{\mathrm{b}}$ & $0.14^{c}$ & $0.09 c$ & $0.61^{\mathrm{a}}$ & 0.05 & $<0.01$ \\
\hline Total SFA & $38.83^{\mathrm{b}}$ & $38.09 \mathrm{~b}$ & $37.44^{\mathrm{b}}$ & $40.29^{a}$ & 0.33 & $<0.01$ \\
\hline Total MUFA & $41.78^{\mathrm{b}}$ & $47.32^{\mathrm{a}}$ & $48.76^{\mathrm{a}}$ & $43.55^{b}$ & 0.68 & $<0.01$ \\
\hline Total PUFA & $18.91^{\mathrm{a}}$ & $13.74^{b}$ & $13.97^{b}$ & $15.60^{\mathrm{b}}$ & 0.54 & $<0.01$ \\
\hline Total n-3 PUFA 3 & $1.01^{\mathrm{a}}$ & $0.70^{\mathrm{b}}$ & $0.64^{\mathrm{b}}$ & $1.39^{a}$ & 0.08 & $<0.01$ \\
\hline Total n-6 PUFA 4 & $17.90^{\mathrm{a}}$ & $12.96^{\mathrm{b}}$ & $13.33^{\mathrm{b}}$ & $13.83^{b}$ & 0.50 & $<0.01$ \\
\hline PUFA:SFA ratio ${ }^{5}$ & $0.46^{\mathrm{a}}$ & $0.36^{\mathrm{b}}$ & $0.37^{b}$ & $0.38^{\mathrm{b}}$ & 0.01 & $<0.01$ \\
\hline n-6:n-3 PUFA ratio 6 & $18.98^{a}$ & $18.93^{a}$ & $21.67 \mathrm{a}$ & $11.87^{b}$ & 0.92 & $<0.01$ \\
\hline Atherogenic index ${ }^{7}$ & $0.50^{\mathrm{b}}$ & $0.49 \mathrm{~b}$ & $0.48^{\mathrm{b}}$ & $0.53^{\mathrm{a}}$ & 0.01 & 0.02 \\
\hline
\end{tabular}

${ }_{1}^{1}$ Pigs ( $\left.n=96\right)$ were fed either a corn-soybean meal diet containing $1.5 \%$ soybean oil (SO; control) or diets containing with $3 \% \mathrm{SO}$, canola oil (CO), or fish oil (FO). Values represent the least square means from a subset of pigs $(n=72 ; 18$ pigs/treatment $) ;{ }^{2} \mathrm{SEM}=$ standard error of the least square means; ${ }^{3}$ Total n-3 PUFA $=\{[C 18: 3$ n-3 $]+[C 20: 5$ n-3 $]+[C 22: 6$ n-3 $]\} ;{ }^{4}$ Total n-6 PUFA = C18:2 n-6; ${ }^{5}$ PUFA:SFA ratio = total PUFA/total SFA; ${ }^{6} \sum \mathrm{n}-6 / \Sigma \mathrm{n}-3$ PUFA ratio; ${ }^{7}$ Atherogenic index $=(4 \times[\mathrm{C} 14: 0])$ $+(\mathrm{C} 16: 0) /($ total MUFA] + [total PUFA] $)$, where brackets indicate concentrations [107] ${ }^{\mathrm{a}-\mathrm{c} W i t h i n}$ a row, values without a common superscript differ $(\mathrm{P} \leq 0.05)$ or tended to differ $(0.05<\mathrm{P} \leq 0.10)$ using Tukey's method. Adapted from [94].

\section{Fatty Acids and Liver}

The liver is involved in the regulation of several metabolic processes and, it is not only crucial for fat metabolism, but in pigs, the liver is an essential site for cholesterol regeneration, synthesis of FA oxidation, and plays an essential role in digestive function, red blood cell breakdown, and hormone production and detoxification [16], [46].

In addition, the liver actively participates in the conversion of dietary energy to TAG, which is exported via VLDL to adipose tissue for storage, or to muscle for usage. It is important for the synthesis of bile acids because it allows the intestinal absorption of HDL dietary fats and transports excess cholesterol from these tissues back to the liver [108]. 
A study analyzing of pigs fed diets enriched with LA and ALA compared to a standard diet showed differences in FA profile with higher amounts of PUFA in the liver in pigs fed LA or ALA [16]. Low availability of LC n-3 PUFA favors the synthesis of FA and TAG over FA breakdown, leading to fat accumulation in the liver. The imbalance in the ratio of n-6 and n-3 PUFA may affect the liver [109].

Gene expression analysis performed in the study of Ramayo-Caldas et al. [46], in selected pigs with extreme phenotypes - High $(\mathrm{H})$ and Low $(\mathrm{L})$ - for intramuscular FA composition revealed 55 DEG between the extreme animals associated with lipid metabolism, small molecule biochemistry, and molecular transport. Within-group $\mathrm{H}$, some genes were found to be positively regulated, playing a fundamental role in cholesterol metabolism, lipoprotein synthesis, oxidation of lipids and palmitic FA, and induction of lipogenic gene transcription. On the other hand, the genes for triacylglycerol accumulation (AQP7), lipid and myristic acid uptake (THBS1), and fatty acid biosynthesis (ME3) were downregulated in group $\mathrm{H}$.

\section{Fatty Acids and Brain}

The central nervous system, which is responsible for receiving and processing information, consists of the brain (cerebrum, cerebellum, and brainstem) and the spinal cord. The brain has in its composition, the outer part of the cerebral cortex, which consists of gray matter, and the inner part, which consists of white matter [110]. The gray matter has this name because of its "coloring," which is due to the large concentration of neuronal cell bodies. It also has dendrites in its composition and, to a lesser extent, a myelinated axon [110], [111]. The cerebral cortex is responsible for processing information that is later released for signal transmission in the axons, which are in the white matter rich in dendrites and axons [111]-[113]. The cortex is also responsible for memory, emotion, and movement. Studies have demonstrated that cortex is associated with neurodegenerative diseases such as Alzheimer's and Parkinson's [110], [114].

Brain tissue with high lipid content has among the FA in its composition DHA, which is considered the most important, representing up to one-third of the total FA in brain gray matter [55], [115]. The DHA participates in modulating the activity of signaling pathways in the brain through its presence in neuronal membrane phospholipids, in addition to being found mainly in synaptosomes, mitochondria, and synaptic vesicles [55], [60], [116].

Gray matter has high PUFA indices, in contrast to the myelin fraction of white matter, which has low levels of PUFA and higher levels of MUFA such as OA and also SFA [55], [60], [116]. Studies show that PUFA have effects on brain functions, such as changes in the affinity of receptors, the activity of neurotransmitters, and production [58].

The brain is a tissue that requires FA with a high degree of unsaturation to maintain normal conditions [66]. Thus, very LC-FA, such as AA and DHA, are important for the development and function of the entire central nervous system. Diets deficient in these FA may cause an increase in DPA and a decrease in DHA [25], [55], [81]. Brain uptake of LC-PUFA can occur directly from the diet or through supplementation LA and ALA, which are converted to long-chain-PUFA [53], [55], [116]-[118]. 
The structure of the neuronal membrane is the most important factor in maintaining its proper function. In addition to structure, lipid composition is also an important factor, as it can be affected by the availability of FA in the diet, thus affecting the fluidity index of the membrane and hindering physiological processes. For example, cholesterol has a reducing effect and PUFA acts by increasing fluidity [25], [55]. Some FA, such as LA and ALA, may help reduce cholesterol in the neuronal membrane, improving this index. However, some studies have suggested that large reductions may compromise the membrane fluidity index, hindering the performance of cellular functions and increasing susceptibility to injury, even leading to cell death [25], [55].

This fluidity may also be altered by the ratio of n-3/n-6 and by the absolute content of FA in cell membranes; however, some studies have demonstrated that the mechanism leading to the lowering of cholesterol levels is not clear [53], [61]. According to Bourre et al. [119], ALA is responsible for the composition of FA in membranes and has an inverse relationship with cholesterol levels. Salem and Niebyski [120] reported that cholesterol levels and membrane function composition are controlled by DHA. Other studies also indicated that an n-3/n-6 ratio of 1:4 promotes the lowering of membrane cholesterol levels and helps to optimize the uptake of PUFA, which promotes better incorporation of FA into neuronal membranes [25], [55].

\section{Fatty Acids in Pig Nutrition}

The FA from plants and animals are used to formulate pig's feed on the pork production chain to bring improvements in production and animal welfare [66], [121][123]. However, to prevent Bovine Spongiform Encephalopathy (BSE), the use of animal by-products was prohibited by the Ministry of Agriculture, Livestock, and Supply (MAPA) for ruminants; however, it is allowed for pigs and poultry nutrition [123]. The Animal Feed Companies use byproducts from pigs to formulate feed for laying hens, poultry, and turkeys, and they use byproducts from laying hens, poultry, or turkeys to formulate feed for pigs. For example, the feed factory inside the vertical integration may use FA from the poultry slaughterhouse to formulate feed for raised pigs. In the tropical part of Brazil, during the summer, it is common practice to include $6 \%$ soybean oil in diets for lactating sows to attempt the energy requirements, because this ingredient has a low caloric increment and lactating sows decrease the feed ingestion during the hot weather of the year. It happens especially in farms where owners have not installed machines to control the internal temperature, such as cooling pads combined with fans. The limitation to this practice, the use of the fat animal to formulate the feed, is the fact that it is not good to include the fat animal as an energy source in the gilts' feed for "flushing" management. In this particular reproductive management of gilts, occurs an increase in energy intake and energy from glucose must be used because the goal of this management is to increase insulin, which causes a positive feedback loop with IGF-I, which in turn leads to an increase in follicle stimulating hormone (FSH) and luteinizing hormone (LH). Then, the most important energy source in this case is starch from corn. It's important to remember that when using fat as an energy source, the correct levels of the A, D, E, and K vitamins as well as antioxidants have to be included to prevent rancidity, since pigs have a good smell capacity. 
Apart from this, it is very interesting to discuss the use of some other specific classes of oils in feed production: plant based essential oils. These classes of oils are responsible for the aroma and flavor of pepper, onion, garlic, oregano, citrus, coconut, etc., for example [124]. Some specific essential plant-based oils can control the growth of bacteria in the intestinal tract of piglets in the rearing and finishing phase and they can replace the antibiotics used in animal production as growth promoters. For example, the coconut industry produces a lot of lauric acids, which have a good antimicrobial effect on various bacteria and can therefore be used for this purpose. Lauric acids it is used as a food additive and has antimicrobial and immunomodulatory activity [99]. However, there is a slight problem with the use of lauric acid in the pet food industry: the shampoo industry buys a substantial amount of the lauric acids on the market. But other essential oils can be explored by animal feed manufacturers. In Brazil, a company called "Phytus Feed ${ }^{\circledR}$ (Prophytus in the past) has isolated some specific essential oils from three different plants: Copaiba (Copaifera langsdorffii), Bean (Ricinus communis), and Cashew (Anacardium occientale). This company developed a product called "Sui pepper phytus ${ }^{\circledR} "$, which has good control of Salmonella sp. and other important pathogenic microorganisms of pigs.

Some Brazilian universities and research institutes are investigating the properties of plant based essential oils from the "Cerrado" (Brazilian savannas) such as peki (Caryocar brasiliense), Jatoba (Hymenaea courbaril), cerrados' cherry - "pitanga" (Eugenia uniflora), sour soup - "Graviola" (Annona muricata) and others. These universities and research institutes collaborate in a large consortium called "Rede FitoCerrado" ("Cerrados' Phyto networking") [125]. With the international pressure to stop or reduce the use of antibiotics in animal production, essential oils seem to be a good alternative to replace antibiotics as growth promoters in pork production [126]. Another implication of essential oils is the possibility that they may have an impact on pig epigenetics when used as additives to formulate diets. Some authors refer to this new research field as "nutriepigenomic" [127].

\section{Sequencing Technologies, Gene Expression and Fatty Acid Regulation}

The advent of high-throughput technology, as next-generation sequencing (NGS), has enabled the identification of transcriptome changes in nutrigenomic studies [16]. These technologies allow the measurement of the expression of each gene in each tissue of an individual using techniques such as RNA-seq [128]. In addition, this tool is widely used to characterize and compare gene expression profiles for the identification of transcripts with different expression patterns between two or more biological conditions of interest in tissue samples [129].

There are other technologies available to understand the genetic machinery involved with interest traits, such as PacBio sequencing, which is third generation sequencing (TGS). The PacBio is a technology that offers longer read lengths when compared with other techniques and it is interesting if the idea is to study larger genomes, quantifying known and new isoforms, applied together with second-generation sequencing, or even directly detect base modifications (methylation) [130]. Moreover, with this technology, better accuracy can be achieved due to increased coverage or hybrid sequencing [130]. The standard to unravel the transcriptome is next-generation RNA-seq technology that has 
become the tool that allows the production of a genome-scale sample-specific transcriptome map [131]. The study of processes involving RNA is extremely important for a better understanding of the genetic variation, gene transcription profile, and transcriptional regulation [132].

The transcriptome is the complete set of transcripts in a cell at a given time. It is quantified, in a physiological state or at a particular developmental stage [64]. Transcriptomics provides a direct insight into the features involved in gene expression and has as the main objective the analysis of the presence or absence and quantification of a transcript [133]. Also, with this kind of analysis, it is possible to verify the posttranscriptional modifications, such as pattern and assessment of alternative splicing, the quantitative assessment of the influence of genotype on gene expression - using eQTL or allele-specific expression analysis (ASE), the gene expression levels and changes under different conditions and, also, to determine the transcriptional structure of genes [65], [133], [134].

The RNA-seq is often used as a strategy to identify DEG but may also be used to reveal mutations in sequences, such as SNP [64], [133], [134]. Analyze of gene expression regulation is very important to link genotypes to traits of interest. The synthesis and maturation of RNAs compose complex gene expression networks that ultimately lead to biological processes. To adapt to different conditions, these networks must be robust and flexible so that they can quickly adapt to adversities that occur genetically or in the environment. Therefore, a thorough knowledge of the principles and mechanisms involved in these complex processes may help for a better understanding of the activities of diseases and signaling pathways associated with traits of interest [134]-[136].

For DEG analysis using RNA-seq technology, it is necessary to follow a standard workflow that starts with total RNA extraction, followed by rRNA depletion or mRNA enrichment [64], [134]. This is followed by cDNA synthesis and sequencing library preparation, a key step in RNA-seq as it determines the fidelity of the cDNA data concerning the original RNA. After this step, sequencing is performed on a highthroughput platform. The final steps are computerized and consist of quality control of the sequencing data, followed by removal of adapters and low-quality sequences if necessary. Data filtering is then performed, followed by alignment/mapping against the reference genome, or transcriptome assembly is performed again to generate a genomelevel transcriptional map. In addition, normalization and statistical modeling of the data are performed [64], [136].

Related to FA composition, in a study characterizing SNP chips and Bayesian methods, nine genomic regions (1Mb windows) were identified associated with fat deposition and FA composition in Nellore beef that explained $1 \%$ of the genotypic variation for FA important for human health, such as ALA, LA, and total n-3 acids. So, using this technology it was possible to identify putative candidate genes present in regions associated with traits of interest aid in understanding the genetic basis of phenotypes and in DNA-based selection strategies [137].

Gene expression is regulated at many levels that involve the transcription, translation, and renewal of mRNA and proteins. During mRNA processing, there are steps of polyadenylation, splicing, and other modifications. Its transport and degradation are 
regulated by RNA binding proteins and non-coding RNAs. Furthermore, protein translation involves several steps and is subject to regulation at different factors [138]. The interaction of nutrition with epigenetic factors is worth to be considered, as changes in gene expression caused by dietary components are controlled by these factors [139].

According to Wang, Gerstein, and Snyder [90], it is important to understand the gene expression to interpret the functional elements of the genome, thus improving animal nutrition and preventing disease. For some transcription factors, activation mechanisms are known. Regarding PPAR- $\gamma$, for instance, the target of thiazolidinediones (TZD) is activated by dietary lipids such as LA, AA, and EPA and their metabolites [140]. This gene is important in regulating several genes involved in lipid metabolism in adipocytes, and also controls the expression of proteins, including fatty acid transporter protein 1 (FATP1) [141].

Among the LC-PUFA n-3, the most notable are the DHA and EPA, which are not only associated with changes in some specific cell signaling pathways and alteration of gene expression but may cause changes in cell membrane properties [29], [91], [92]. Another FA related to the regulation of gene expression in AA, which is also a PUFA, belongs to the $\mathrm{n}-6$ family and is derived from LA [51], [53].

\section{Nutrigenomics}

Nutrigenomics research seeks a deep understanding of the molecular effects of nutrients on gene expression, genome stability, DNA repair, and molecular mechanisms operating in disease. Therefore, the study of "omics" arouses as a powerful tool to investigate the expression of genes in response to the components in the diet. Thus, significant changes have occurred in the field of nutrition.

Advances that focus on patterns of gene expression, protein expression, and metabolite production in response to diet components may influence metabolic programming and have demonstrated impact of diet on health and disease [142]. For example, n-3 and n-6 PUFA have been studied showing their relationship and ability to affect gene expression, as they are substrates for the production of signaling molecules or functional mediators [28].

Studies focusing on nutrigenomics in pigs have been evaluating different diets to better understand the regulation of important biological processes also establishing comparisons with studies in humans [11], [37]. Pigs fed FA enriched diets may increase from a normal $10-15 \%$ FA in adipose tissue up to $30-40 \%$ [37]. In the same species, it is also possible to alter the fat content by feeding and the FA composition [143]. High-fat diets enriched with $4 \%$ inulin decreased backfat thickness and increased hindgut microbial diversity in the Ossabaw pig model, suggesting that concurrent consumption of fermentable fiber could avoid some of the adverse effects of high-fat diets [144].

A study by Zabek et. al. [145] found that feeding pigs with a diet containing high amounts of fat led to changes in the aorta thickness. Similarly, Milenkovic et. al. [146] evaluated the transcriptome of the intima and middle aorta and found DEG in relation to animals that received the control diet. And even after a change in the high fat to the lowfat diet, it was not possible to reverse the alterations in the arterial transcriptome, which 
may be related to the higher incidence of cardiovascular diseases. However, Ballester et. al. [147] evaluated the liver and adipose tissue (visceral and subcutaneous) transcriptome of 20 pigs submitted to four dietary treatments (conventional diet; a Western diet; and a Western diet containing Bifidobacterium breve and hydrolysate, either with or without the addition of n-3) for 10 weeks. Differential expression gene analysis concluded an increase in cholesterogenesis, lipogenesis, and inflammatory processes in animals on the westerntype diet. In relation to supplementation with bioactive ingredients, there was an induction of FA oxidation, a decrease in adipogenesis and inflammation, and induction of cholesterol catabolism.

Regarding the use of FA in swine nutrition, we can observe an increased application because of several benefits. Among these benefits, (1) FA can be used to easily increase the energy density of pig diets, which is important in the feeding of heat-stressed pigs and high producing lactating sows; (2) FA can improve the overall feed efficiency because the animal metabolizes it into body mass live weight gain (carcass weight and lean meat content are desirable); and (3) FA can be utilized as fat-soluble vitamins, essential FA, and molecular signaling, reducing the production cost and increasing the financial return [36], [105], [148], [149].

\section{Conclusions}

The participation of FA in the development of organs and bodies of animals is evident, as well as their importance in the quality of the final product in the food industry (meat quality). Studies involving gene expression associated with nutrigenomics techniques and quality feeding for these animals, contribute to the successful development of improvements in animal meat production and derivatives.

Author Contributions: Writing-original draft preparation, A.S.M.C., S.L.F, B.P.M.S, B.P., M.H.A.S., G.H.G.P., R.C.A.; writing - review and editing, A.S.M.C, S.L.F., B.P.M.S, B.P., V.V.A, G.C.M.M., J.C.C.B., J.M.R., D.K., A.L.F., L.L.C.; supervision, A.S.M.C. All authors have read and agreed to the published version of the manuscript.

Funding: This study was supported by the São Paulo Research Foundation (FAPESP, Grant numbers: 2020/10042-6, 2018/25180-2, 2018/15653-3, 2018/26797- 6, 2018/26816-0, and 2014/02493-7, the Brazilian National Council for Scientific and Technological Development (CNPq) that provided a researcher fellowship to A. S. M. Cesar, L. L. Coutinho and Coordination for the Improvement of Higher Education Personnel - Brazil (CAPES) - Finance Code 001.

Institutional Review Board Statement: Not applicable.

Data Availability Statement: Not applicable.

Acknowledgments: We acknowledge the collaborative efforts among University of São Paulo and Iowa State University. Appreciation is extended to DB Genética Suína and gratefully acknowledge the support of Crista Indústria e Comércio Ltda and Patense Indústria de Rendering.

Conflicts of Interest: The authors declare no conflict of interest. 


\section{Abbreviations}

AA Arachidonic acid

ACSVL very long-chain acyl-CoA synthetases

ADHD Attention deficit hyperactivity disorder

ALA Alpha-linolenic acid

ASE Allele-specific expression

BSE Bovine spongiform encephalopathy

cDNA complementary DNA

CLA Conjugated linoleic acid

D6D Delta-6-desaturase

DEG Differentially expressed genes

DHA Docosahexaenoic acid

DPA Docosapentaenoic acid

EPA Eicosapentaenoic acid

eQTLexpression Quantitative Trait Loci

FA Fatty acids

FABPpm Fatty acids binding protein

FAT Fatty acid translocase

FATP Fatty acid transport protein

FFA Free fatty acids

FSH Follicle stimulating hormone

HDL High-density lipoprotein

IGF-I Insulin-like Growth Factor-1

LA Linoleic acid

LC Long chain

LDL Low-density lipoprotein

LH Luteinizing hormone

LPL Lipase lipoprotein

LXR Liver X receptors

mRNA messenger RNA

MUFA Monounsaturated fatty acids

NAFLD Non-alcoholic fatty liver disease

NFAT Nuclear factor of activated T cells

NGS Next-generation sequencing

OA Oleic Acid

PPAR Peroxisome proliferator-activated receptors

PUFA Polyunsaturated fatty acids

RNA-seq RNA sequencing

rRNA ribosomal RNA

RXR Retinoid X Receptors

SFA Saturated fatty acids

SNP Single Nucleotide Polymorphisms

SREBP Sterol regulatory element-binding protein 


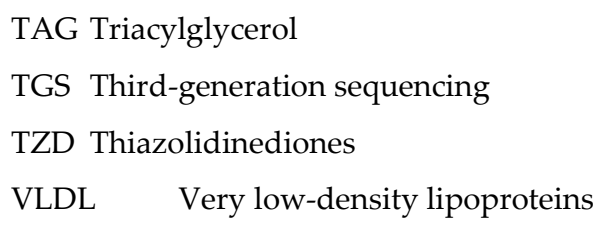

\section{References}

1. World Population Review. World Population Review. 2021;68-70.

2. Daniel CR, Cross AJ, Koebnick C, Sinha R. Trends in meat consumption in the USA. Public Health Nutr. 2011 Apr;14(4):575-83.

3. OECD-FAO. OECD-FAO Agricultural Outlook 2021-2030. OECD-FAO Agric Outlook 2021-2030. 2021;163-77.

4. Rosenvold K, Andersen HJ. Factors of significance for pork quality - a review. Meat Sci. 2003 Jul;64(3):219-37.

5. Mourot J, Hermier D. Lipids in monogastric animal meat. Reprod Nutr Dev. 2001 Mar;41(2):109-18.

6. Rentfrow G, Sauber TE, Allee GL, Berg EP. The influence of diets containing either conventional corn, conventional corn with choice white grease, high oil corn, or high oil high oleic corn on belly/bacon quality. Meat Sci. 2003 Aug 1;64(4):459-66.

7. Hasan MS, Feugang JM, Liao SF. A Nutrigenomics Approach Using RNA Sequencing Technology to Study Nutrient-Gene Interactions in Agricultural Animals. Curr Dev Nutr. 2019 Aug;3(8).

8. Zempleni J, Daniel H. Molecular nutrition. 2003;

9. Norheim F, Gjelstad IMF, Hjorth M, Vinknes KJ, Langleite TM, Holen T, et al. Molecular Nutrition ResearchThe Modern Way Of Performing Nutritional Science. Nutr 2012, Vol 4, Pages 1898-1944. 2012 Dec;4(12):1898944.

10. Lunney JK. Advances in swine biomedical model genomics. Vol. 3, International Journal of Biological Sciences. 2007.

11. Pan et al. Pig genome functional annotation enhances the biological interpretation of complex traits and human disease. Nat Commun. 2021;12.

12. Schook LB, Collares T V., Darfour-Oduro KA, De AK, Rund LA, Schachtschneider KM, et al. Unraveling the swine genome: Implications for human health. Annu Rev Anim Biosci. 2015;3.

13. Doreau M, Chilliard Y. Digestion and metabolism of dietary fat in farm animals. Br J Nutr. 1997;78(1).

14. Bassols A, Costa C, Eckersall PD, Osada J, Sabrià J, Tibau J. The pig as an animal model for human pathologies: A proteomics perspective. Vol. 8, Proteomics - Clinical Applications. 2014.

15. Groenen MAM, Archibald AL, Uenishi H, Tuggle CK, Takeuchi Y, Rothschild MF, et al. Analyses of pig genomes 
provide insight into porcine demography and evolution. Nature. 2012;491(7424).

16. Szostak A, Ogłuszka M, Te Pas MFW, Poławska E, Urbański P, Juszczuk-Kubiak E, et al. Effect of a diet enriched with omega-6 and omega-3 fatty acids on the pig liver transcriptome. Genes Nutr. 2016;11(1):1-17.

17. Crespo-Piazuelo D, Criado-Mesas L, Revilla M, Castelló A, Fernández AI, Folch JM, et al. Indel detection from Whole Genome Sequencing data and association with lipid metabolism in pigs. PLoS One. 2019;14(6):1-17.

18. FAO. Meat market review. Overview of global meat market developments in 2020. Food Agric Organ United Nations. 2020;(December).

19. Associação Brasileira de Proteína Animal. Relatório Anual 2020 [Internet]. 2020. Available from: http://abpabr.org/relatorios/

20. Park JC, Kim SC, Lee SD, Jang HC, Kim NK, Lee SH, et al. Effects of dietary fat types on growth performance, pork quality, and gene expression in growing-finishing pigs. Asian-Australasian J Anim Sci. 2012;25(12).

21. Dugan M, Vahmani P, Turner T, Mapiye C, Juárez M, Prieto N, et al. Pork as a Source of Omega-3 (n-3) Fatty Acids. J Clin Med. 2015;4(12).

22. Wood JD, Enser M, Fisher A V., Nute GR, Sheard PR, Richardson RI, et al. Fat deposition, fatty acid composition and meat quality: A review. Meat Sci. 2008;78(4):343-58.

23. Song $\mathrm{CH}$, Oh SM, Lee $\mathrm{SH}$, Choi $\mathrm{YH}$, Kim JD, Jang A, et al. The ratio of dietary n-3 polyunsaturated fatty acids influences the fat composition and lipogenic enzyme activity in adipose tissue of growing pigs. Food Sci Anim Resour. 2020;40(2).

24. Światkiewicz M, Oczkowicz M, Ropka-Molik K, Hanczakowska E. The effect of dietary fatty acid composition on adipose tissue quality and expression of genes related to lipid metabolism in porcine livers. Anim Feed Sci Technol. 2016;216:204-15.

25. Caterina R De. n-3 Fatty Acids in Cardiovascular Disease. N Engl J Med. 2011;

26. Baker EJ, Miles EA, Burdge GC, Yaqoob P, Calder PC. Metabolism and functional effects of plant-derived omega3 fatty acids in humans. Vol. 64, Progress in Lipid Research. 2016.

27. Ollis TE, Meyer BJ, Howe PRC. Australian food sources and intakes of omega- 6 and omega-3 polyunsaturated fatty acids. Ann Nutr Metab. 1999;43(6).

28. Cesar ASM, Regitano LCA, Poleti MD, Andrade SCS, Tizioto PC, Oliveira PSN, et al. Differences in the skeletal muscle transcriptome profile associated with extreme values of fatty acids content. BMC Genomics. 2016 Nov $22 ; 17(1)$.

29. Georgiadi A, Kersten S. Mechanisms of gene regulation by fatty acids. Adv Nutr. 2012;3(2):127-34.

30. Revilla M, Puig-Oliveras A, Crespo-Piazuelo D, Criado-Mesas L, Castelló A, Fernández AI, et al. Expression analysis of candidate genes for fatty acid composition in adipose tissue and identification of regulatory regions. Sci Rep. 2018;8(1). 
31. Andersen HJ, Oksbjerg N, Young JF, Therkildsen M. Feeding and meat quality - A future approach. In: Meat Science. 2005.

32. Corino C, Magni S, Pagliarini E, Rossi R, Pastorelli G, Chiesa LM. Effects of dietary fats on meat quality and sensory characteristics of heavy pig loins. Meat Sci. 2002;60(1).

33. Wood JD, Richardson RI, Nute GR, Fisher A V., Campo MM, Kasapidou E, et al. Effects of fatty acids on meat quality: A review. Meat Sci. 2004;66(1).

34. Øverland M, Haug A, Sundstøl E, Taugbøl O. Effect of fish oil on growth performance, carcass characteristics, sensory parameters, and fatty acid composition in pigs. Acta Agric Scand A Anim Sci. 1996;46(1).

35. Burnett DD, Legako JF, Phelps KJ, Gonzalez JM. Biology, strategies, and fresh meat consequences of manipulating the fatty acid composition of meat. Vol. 98, Journal of animal science. 2020.

36. Lauridsen C, Bruun Christensen T, Halekoh U, Krogh Jensen S. Alternative fat sources to animal fat for pigs. Lipid Technol. 2007;19(7):156-9.

37. Kyriazakis I, Whittemore CT. Whittemore's Science and Practice of Pig Production. 3rd ed. Whittemore's Science and Practice of Pig Production. 2006. 360-368 p.

38. Raes K, De Smet S, Demeyer D. Effect of dietary fatty acids on incorporation of long chain polyunsaturated fatty acids and conjugated linoleic acid in lamb, beef and pork meat: A review. Anim Feed Sci Technol. 2004;113(1-4).

39. Woods VB, Fearon AM. Dietary sources of unsaturated fatty acids for animals and their transfer into meat, milk and eggs: A review. Vol. 126, Livestock Science. 2009.

40. Amusquivar E, Laws J, Clarke L, Herrera E. Fatty Acid Composition of the Maternal Diet During the First or the Second Half of Gestation Influences the Fatty Acid Composition of Sows' Milk and Plasma, and Plasma of Their Piglets. Lipids 2010 455. 2010 Apr;45(5):409-18.

41. Clouard C, Kemp B, Val-Laillet D, Gerrits WJJ, Bartels AC, Bolhuis JE. Prenatal, but not early postnatal, exposure to a Western diet improves spatial memory of pigs later in life and is paired with changes in maternal prepartum blood lipid levels. FASEB J. 2016 Jul;30(7):2466-75.

42. Luo WL, Luo Z, Xu X, Zhao S, Li SH, Sho T, et al. The effect of maternal diet with fish oil on oxidative stress and inflammatory response in sow and new-born piglets. Oxid Med Cell Longev. 2019;2019.

43. Vodolazska D, Lauridsen C. Effects of dietary hemp seed oil to sows on fatty acid profiles, nutritional and immune status of piglets. J Anim Sci Biotechnol 2020 111. 2020 Mar;11(1):1-18.

44. Harris WS, Assaad B, Poston WC. Tissue Omega-6/Omega-3 Fatty Acid Ratio and Risk for Coronary Artery Disease. Am J Cardiol. 2006;98(4 SUPPL. 1).

45. Guillevic M, Kouba M, Mourot J. Effect of a linseed diet on lipid composition, lipid peroxidation and consumer evaluation of French fresh and cooked pork meats. Meat Sci. 2009;81(4).

46. Ramayo-Caldas Y, Mach N, Esteve-Codina A, Corominas J, Castelló A, Ballester M, et al. Liver transcriptome 
profile in pigs with extreme phenotypes of intramuscular fatty acid composition. BMC Genomics. 2012;13(1).

47. Duan Y, Li F, Li L, Fan J, Sun X, Yin Y. N-6:n-3 PUFA ratio is involved in regulating lipid metabolism and inflammation in pigs. Br J Nutr. 2014;111(3).

48. Petrovic S, Arsic A. Fatty Acids: Fatty Acids. Encycl Food Heal. 2016 Jan 1;623-31.

49. Moghadasian MH, Shahidi F. Fatty Acids. Int Encycl Public Heal. 2017 Jan 1;114-22.

50. Nakamura MT, Nara TY. Essential fatty acid synthesis and its regulation in mammals. Prostaglandins, Leukot Essent Fat Acids. 2003 Feb 1;68(2):145-50.

51. Eshak ES, Yamagishi K, Iso H. Dietary Fat and Risk of Cardiovascular Disease. In: Encyclopedia of Cardiovascular Research and Medicine. 2018.

52. Youdim KA, Martin A, Joseph JA. Essential fatty acids and the brain: Possible health implications. Int J Dev Neurosci. 2000;18(4-5).

53. Elmadfa I, Kornsteiner M. Dietary fat intake - A global perspective. In: Annals of Nutrition and Metabolism. 2009.

54. Thompson TE. “Lipid.” Encycl Br [Internet]. 2021; Available from: https://www.britannica.com/science/lipid.

55. Yehuda S, Rabinovitz S, Carasso RL, Mostofsky DI. The role of polyunsaturated fatty acids in restoring the aging neuronal membrane. Neurobiol Aging. 2002;23(5).

56. Guasch-Ferré M, Hu FB, Martínez-González MA, Fitó M, Bulló M, Estruch R, et al. Olive oil intake and risk of cardiovascular disease and mortality in the PREDIMED Study. BMC Med. 2014;12(1).

57. De Lorgeril M, Salen P. Mediterranean diet and n-3 fatty acids in the prevention and treatment of cardiovascular disease. In: Journal of Cardiovascular Medicine. 2007.

58. YEHUDA, S.; MOSTOFSKY DI. Handbook of Essential Fatty Acid Biology. Danvers, MA: Humana Press; 1997.

59. Calder PC. Functional Roles of Fatty Acids and Their Effects on Human Health. Vol. 39, Journal of Parenteral and Enteral Nutrition. 2015. p. 18S-32S.

60. Neuringer M, Anderson GJ, Connor WE. The essentiality of N-3 fatty acids for the development and function of the retina and brain. Vol. 8, Annual Review of Nutrition. 1988.

61. Bork CS, Veno SK, Lasota AN, Lundbye-Christensen S, Schmidt EB. Marine and plant-based n-3 PUFA and atherosclerotic cardiovascular disease. Proc Nutr Soc. 2020;79(1).

62. Jakobsen MU, O'Reilly EJ, Heitmann BL, Pereira MA, Bälter K, Fraser GE, et al. Major types of dietary fat and risk of coronary heart disease: A pooled analysis of 11 cohort studies. Am J Clin Nutr. 2009;89(5).

63. Burr GO, Burr MM. On the nature and rôle of the fatty acids essential in nutrition. Vol. 20, Progress in Lipid Research. 1981. 
64. Wang Z, Gerstein M, Snyder M. RNA-Seq: A revolutionary tool for transcriptomics. Vol. 10, Nature Reviews Genetics. 2009.

65. Lehnen TE, da Silva MR, Camacho A, Marcadenti A, Lehnen AM. A review on effects of conjugated linoleic fatty acid (CLA) upon body composition and energetic metabolism. Vol. 12, Journal of the International Society of Sports Nutrition. 2015.

66. Ferronato G, Prandini A. Dietary supplementation of inorganic, organic, and fatty acids in pig: A review. Vol. 10, Animals. 2020.

67. Thompson BR, Lobo S, Bernlohr DA. Fatty acid flux in adipocytes: The in's and out's of fat cell lipid trafficking. Mol Cell Endocrinol. 2010 Apr 29;318(1-2):24-33.

68. Bradbury MW. Lipid metabolism and liver inflammation. I. Hepatic fatty acid uptake: Possible role in steatosis. Am J Physiol - Gastrointest Liver Physiol. 2006;290(2).

69. Alves-Bezerra M, Cohen DE. Triglyceride metabolism in the liver. Compr Physiol. 2018;8(1).

70. Kersten S, Desvergne B, Wahli W. Roles of PPARS in health and disease. Nature. 2000;405(6785).

71. Hostetler HA, Petrescu AD, Kier AB, Schroeder F. Peroxisome proliferator-activated receptor $\alpha$ interacts with high affinity and is conformationally responsive to endogenous ligands. J Biol Chem. 2005;280(19).

72. Fang X, Hu S, Xu B, Snyder GD, Harmon S, Yao J, et al. 14,15-Dihydroxyeicosatrienoic acid activates peroxisome proliferator-activated receptor- $\alpha$. Am J Physiol - Hear Circ Physiol. 2006;290(1).

73. Poletto AC, Furuya DT, David-Silva A, Ebersbach-Silva P, Corrêa-Giannella ML, Passarelli M, et al. Oleic and linoleic fatty acids downregulate Slc2a4/GLUT4 expression via NFKB and SREBP1 in skeletal muscle cells. Mol Cell Endocrinol. 2015;401.

74. Gormaz JG, Rodrigo R, Videla LA, Beems M. Biosynthesis and bioavailability of long-chain polyunsaturated fatty acids in non-alcoholic fatty liver disease. Vol. 49, Progress in Lipid Research. 2010.

75. Vallim T, Salter AM. Regulation of hepatic gene expression by saturated fatty acids. Prostaglandins Leukot Essent Fat Acids. 2010;82(4-6).

76. Jump DB, Botolin D, Wang Y, Xu J, Christian B, Demeure O. Fatty acid regulation of hepatic gene transcription. Vol. 135, Journal of Nutrition. 2005.

77. Oczkowicz M, Szmatoła T, Świątkiewicz M, Koseniuk A, Smołucha G, Witarski W, et al. 3'quant mRNA-seq of porcine liver reveals alterations in upr, acute phase response, and cholesterol and bile acid metabolism in response to different dietary fats. Genes (Basel). 2020;11(9).

78. Li D, Ng A, Mann NJ, Sinclair AJ. Contribution of meat fat to dietary arachidonic acid. Lipids. 1998;33(4):437-40.

79. Yehuda S, Rabinovitz S, Mostofsky DI. Essential fatty acids are mediators of brain biochemistry and cognitive functions. Vol. 56, Journal of Neuroscience Research. 1999. 
80. Li D, Ng A, Mann NJ, Sinclair AJ. Contribution of meat fat to dietary arachidonic acid. Lipids. 1998;33(4).

81. Martin CA, De Almeida VV, Ruiz MR, Visentainer JEL, Matshushita M, De Souza NE, et al. Ácidos graxos poliinsaturados ômega-3 e ômega-6: Importância e ocorrência em alimentos. Rev Nutr. 2006;19(6).

82. Yokoyama M, Origasa H, Matsuzaki M, Matsuzawa Y, Saito Y, Ishikawa Y, et al. Effects of eicosapentaenoic acid on major coronary events in hypercholesterolaemic patients (JELIS): a randomised open-label, blinded endpoint analysis. Lancet. 2007;369(9567).

83. Bork CS, Jakobsen MU, Lundbye-Christensen S, Tjønneland A, Schmidt EB, Overvad K. Dietary intake and adipose tissue content of $\alpha$-linolenic acid and risk of myocardial infarction: A Danish cohort study. Am J Clin Nutr. 2016;104(1).

84. Studer M, Briel M, Leimenstoll B, Glass TR, Bucher HC. Effect of different antilipidemic agents and diets on mortality: A systematic review. Vol. 165, Archives of Internal Medicine. 2005.

85. Marik PE, Varon J. Omega-3 dietary supplements and the risk of cardiovascular events: A systematic review. Vol. 32, Clinical Cardiology. 2009.

86. Casula M, Soranna D, Catapano AL, Corrao G. Long-term effect of high dose omega-3 fatty acid supplementation for secondary prevention of cardiovascular outcomes: A meta-analysis of randomized, double blind, placebo controlled trials. Atheroscler Suppl. 2013;14(2).

87. Smith GI, Atherton P, Reeds DN, Mohammed BS, Rankin D, Rennie MJ, et al. Dietary omega-3 fatty acid supplementation increases the rate of muscle protein synthesis in older adults: A randomized controlled trial. Am J Clin Nutr. 2011;93(2).

88. Calder PC. Very long chain omega-3 (n-3) fatty acids and human health. Eur J Lipid Sci Technol. 2014;116(10):1280-300.

89. Chowdhury R, Warnakula S, Kunutsor S, Crowe F, Ward HA, Johnson L, et al. Association of dietary, circulating, and supplement fatty acids with coronary risk: A systematic review and meta-analysis. Ann Intern Med. $2014 ; 160(6)$.

90. Navarro MA, Acín S, Iturralde M, Calleja L, Carnicer R, Guzmán-García MA, et al. Cloning, characterization and comparative analysis of pig plasma apolipoprotein A-IV. Gene. 2004 Jan 21;325(1-2):157-64.

91. Nakamura MT, Cheon Y, Li Y, Nara TY. Mechanisms of regulation of gene expression by fatty acids. In: Lipids. 2004.

92. Turk HF, Chapkin RS. Membrane lipid raft organization is uniquely modified by n-3 polyunsaturated fatty acids. Prostaglandins Leukot Essent Fat Acids. 2013;88(1).

93. Eaton SB, Eaton SB, Sinclair AJ, Cordain L, Mann NJ. Dietary intake of long-chain polyunsaturated fatty acids during the paleolithic. World Rev Nutr Diet. 1998;83.

94. Almeida V V., Silva JPM, Schinckel AP, Meira AN, Moreira GCM, Gomes JD, et al. Effects of increasing dietary 
oil inclusion from different sources on growth performance, carcass and meat quality traits, and fatty acid profile in genetically lean immunocastrated male pigs. Livest Sci. 2021 Jun 1;248:104515.

95. Simopoulos AP. Importance of the omega-6/omega-3 balance in health and disease: Evolutionary aspects of diet. World Rev Nutr Diet. 2011;102.

96. Simopoulos AP. Importance of the ratio of omega-6/omega-3 essential fatty acids: evolutionary aspects. Vol. 92, World review of nutrition and dietetics. 2003.

97. Lopez S, Bermudez B, Montserrat-De La Paz S, Jaramillo S, Varela LM, Ortega-Gomez A, et al. Membrane composition and dynamics: A target of bioactive virgin olive oil constituents. Vol. 1838, Biochimica et Biophysica Acta - Biomembranes. 2014.

98. Sessler AM, Ntambi JM. Polyunsaturated Fatty Acid Regulation of Gene Expression. J Nutr. 2000;130(1 SUPPL.).

99. Jackman JA, Boyd RD, Elrod CC. Medium-chain fatty acids and monoglycerides as feed additives for pig production: Towards gut health improvement and feed pathogen mitigation. J Anim Sci Biotechnol. 2020;11(1).

100. Zhang Y, Zhang J, Gong H, Cui L, Zhang W, Ma J, et al. Genetic correlation of fatty acid composition with growth, carcass, fat deposition and meat quality traits based on GWAS data in six pig populations. Meat Sci. 2019;150.

101. Jeromson S, Gallagher IJ, R Galloway SD, Lee Hamilton D. marine drugs Omega-3 Fatty Acids and Skeletal Muscle Health. Mar Drugs [Internet]. 2015;13:6977-7004. Available from: www.mdpi.com/journal/marinedrugs

102. Cesar ASM, Regitano LCA, Reecy JM, Poleti MD, Oliveira PSN, de Oliveira GB, et al. Identification of putative regulatory regions and transcription factors associated with intramuscular fat content traits. BMC Genomics. 2018 Jun 27;19(1).

103. Berton MP, Fonseca LFS, Gimenez DFJ, Utembergue BL, Cesar ASM, Coutinho LL, et al. Gene expression profile of intramuscular muscle in Nellore cattle with extreme values of fatty acid. BMC Genomics. 2016 Nov 25;17(1).

104. Albracht-Schulte K, Kalupahana NS, Ramalingam L, Wang S, Rahman SM, Robert-McComb J, et al. Omega-3 fatty acids in obesity and metabolic syndrome: a mechanistic update. Vol. 58, Journal of Nutritional Biochemistry. 2018.

105. Horodyska J, Wimmers K, Reyer H, Trakooljul N, Mullen AM, Lawlor PG, et al. RNA-seq of muscle from pigs divergent in feed efficiency and product quality identifies differences in immune response, growth, and macronutrient and connective tissue metabolism. BMC Genomics. 2018;19(1):1-18.

106. Laaksonen DE, Nyyssönen K, Niskanen L, Rissanen TH, Salonen JT. Prediction of cardiovascular mortality in middle-aged men by dietary and serum linoleic and polyunsaturated fatty acids. Arch Intern Med. 2005;165(2).

107. Ulbricht TLV, Southgate DAT. Coronary heart disease: seven dietary factors. Lancet. 1991;338(8773).

108. Horodyska J, Hamill RM, Reyer H, Trakooljul N, Lawlor PG, McCormack UM, et al. RNA-seq of liver from pigs divergent in feed efficiency highlights shifts in macronutrient metabolism, hepatic growth and immune response. Front Genet. 2019;10(feburay). 
109. El-Badry AM, Graf R, Clavien PA. Omega 3 - Omega 6: What is right for the liver? J Hepatol. 2007 Nov 1;47(5):718-25.

110. Mercadante AA, Tadi P. Neuroanatomy, Gray Matter. StatPearls. 2020.

111. Tomassy GS, Berger DR, Chen HH, Kasthuri N, Hayworth KJ, Vercelli A, et al. Distinct profiles of myelin distribution along single axons of pyramidal neurons in the neocortex. Vol. 344, Science. 2014.

112. Dolz J, Desrosiers C, Wang L, Yuan J, Shen D, Ben Ayed I. Deep CNN ensembles and suggestive annotations for infant brain MRI segmentation. Comput Med Imaging Graph. 2020;79.

113. Shofty B, Mauda-Havakuk M, Ben-Sira L, Bokstein F, Lidar Z, Salame K, et al. Surgical Management of "Kissing" Spinal Plexiform Neurofibromas in Neurofibromatosis Type 1 Patients. World Neurosurg. 2020;134.

114. Tijms BM, Yeung HM, Sikkes SAM, Möller C, Smits LL, Stam CJ, et al. Single-subject gray matter graph properties and their relationship with cognitive impairment in early- and late-onset Alzheimer's disease. Brain Connect. 2014;4(5).

115. Chang CY, Ke DS, Chen JY. Essential fatty acids and human brain. Vol. 18, Acta Neurologica Taiwanica. 2009.

116. Sinclair AJ, Attar-Bashi NM, Li D. What is the role of $\alpha$ t-linolenic acid for mammals? Vol. 37, Lipids. 2003.

117. Astorg P, Arnault N, Czernichow S, Noisette N, Galan P, Hercberg S. Dietary intakes and food sources of n-6 and n-3 PUFA in French adult men and women. Lipids. 2004;39(6).

118. DIETARY-FATS. Total fat and fatty acids. Natl Acad Press. 2005;(1ed. New York):422-541.

119. Bourre JM, Dumont O, Piciotti M, Clément M, Chaudière J, Bonneil M, et al. Essentiality of omega 3 fatty acids for brain structure and function. World Rev Nutr Diet. 1991;66.

120. Salem N, Niebylski CD. The nervous system has an absolute molecular species requirement for proper function. Mol Membr Biol. 1995;12(1).

121. Otten W, Wirth C, Iaizzo PA, Eichinger HM. A high omega 3 fatty acid diet alters fatty acid composition of heart, liver, kidney, adipose tissue and skeletal muscle in swine. Ann Nutr Metab. 1993;37(3).

122. Van Oeckel MJ, Casteels M, Warnants N, Van Damme L, Boucqué C V. Omega-3 fatty acids in pig nutrition: Implications for the intrinsic and sensory quality of the meat. Meat Sci. 1996 Sep 1;44(1-2):55-63.

123. Brasil. Instrução Normativa MAPA - 41, de 08/10/2009. Ministério da Agric Pecuária e Abast. 2009;

124. Abers M, Schroeder S, Goelz L, Sulser A, St. Rose T, Puchalski K, et al. Antimicrobial activity of the volatile substances from essential oils. BMC Complement Med Ther. 2021;21(1).

125. Machado HL, Moura VL, Gouveia NM, Costa GA, Espindola FS, Botelho F V. Research and extension activities in herbal medicine developed by Rede FitoCerrado: Rational use of medicinal plants by the elderly in 
Uberlândia-MG. Rev Bras Plantas Med. 2014;16(3).

126. Zhai H, Liu H, Wang S, Wu J, Kluenter AM. Potential of essential oils for poultry and pigs. Vol. 4, Animal Nutrition. 2018.

127. Meroni M, Longo M, Rustichelli A, Dongiovanni P. Nutrition and genetics in NAFLD: The perfect binomium. Vol. 21, International Journal of Molecular Sciences. 2020.

128. Tizioto PC, Coutinho LL, Oliveira PSN, Cesar ASM, Diniz WJS, Lima AO, et al. Gene expression differences in Longissimus muscle of Nelore steers genetically divergent for residual feed intake. Sci Rep. 2016;6.

129. Pareek CS, Sachajko M, Jaskowski JM, Herudzinska M, Skowronski M, Domagalski K, et al. Comparative analysis of the liver transcriptome among cattle breeds using RNA-seq. Vet Sci. 2019;6(2).

130. Rhoads A, Au KF. PacBio Sequencing and Its Applications. Vol. 13, Genomics, Proteomics and Bioinformatics. 2015.

131. Lusk R, Stene E, Banaei-Kashani F, Tabakoff B, Kechris K, Saba LM. Aptardi predicts polyadenylation sites in sample-specific transcriptomes using high-throughput RNA sequencing and DNA sequence. Nat Commun. 2021;12(1).

132. Chen L, Wong G. Transcriptome informatics. In: Encyclopedia of Bioinformatics and Computational Biology: ABC of Bioinformatics. 2018.

133. Manzoni C, Kia DA, Vandrovcova J, Hardy J, Wood NW, Lewis PA, et al. Genome, transcriptome and proteome: The rise of omics data and their integration in biomedical sciences. Brief Bioinform. 2018;19(2).

134. Stark R, Grzelak M, Hadfield J. RNA sequencing: the teenage years. Nat Rev Genet [Internet]. 2019;20(11):63156. Available from: http://dx.doi.org/10.1038/s41576-019-0150-2

135. Schena M, Heller RA, Theriault TP, Konrad K, Lachenmeier E, Davis RW. Microarrays: Biotechnology's discovery platform for functional genomics. Vol. 16, Trends in Biotechnology. 1998.

136. López-Maury L, Marguerat S, Bähler J. Tuning gene expression to changing environments: From rapid responses to evolutionary adaptation. Vol. 9, Nature Reviews Genetics. 2008.

137. Cesar ASM, Regitano LCA, Mourão GB, Tullio RR, Lanna DPD, Nassu RT, et al. Genome-wide association study for intramuscular fat deposition and composition in Nellore cattle. Vol. 15, BMC Genetics. 2014.

138. Buccitelli C, Selbach M. mRNAs, proteins and the emerging principles of gene expression control. Vol. 21, Nature Reviews Genetics. 2020.

139. Jiménez-Chillarón JC, Díaz R, Martínez D, Pentinat T, Ramón-Krauel M, Ribó S, et al. The role of nutrition on epigenetic modifications and their implications on health. Biochimie. 2012 Nov;94(11):2242-63.

140. Ning B, Kaput J. Toward Personalized Nutrition and Medicine: Promises and Challenges. In: Nutrigenomics and Proteomics in Health and Disease: Food Factors and Gene Interactions. 2009. 
141. Tavares V, Hirata MH, Hirata RDC. Receptor ativado por proliferadores de peroxissoma gama (Ppargama): estudo molecular na homeostase da glicose, metabolismo de lipídeos e abordagem terapêutica. Arq Bras Endocrinol Metabol. 2007;51(4).

142. Bordoni L, Gabbianelli R. Primers on nutrigenetics and nutri(epi)genomics: Origins and development of precision nutrition [Internet]. Biochimie 2019. Available from: https://doi.org/10.1016/j.biochi.2019.03.006

143. Teye GA, Sheard PR, Whittington FM, Nute GR, Stewart A, Wood JD. Influence of dietary oils and protein level on pork quality. 1. Effects on muscle fatty acid composition, carcass, meat and eating quality. Meat Sci. 2006 May 1;73(1):157-65.

144. Yan H, Potu R, Lu H, Vezzoni de Almeida V, Stewart T, Ragland D, et al. Dietary Fat Content and Fiber Type Modulate Hind Gut Microbial Community and Metabolic Markers in the Pig. PLoS One. 2013;8(4).

145. Zabek A, Paslawski R, Paslawska U, Wojtowicz W, Drozdz K, Polakof S, et al. The influence of different diets on metabolism and atherosclerosis processes-A porcine model: Blood serum, urine and tissues 1H NMR metabolomics targeted analysis. PLoS One. 2017 Oct;12(10):e0184798.

146. Milenkovic D, Paslawski R, Gomulkiewicz A, Gladine C, Janczak D, Grzegorek I, et al. Alterations of aorta intima and media transcriptome in swine fed high-fat diet over 1-year follow-up period and of the switch to normal diet. Nutr Metab Cardiovasc Dis. 2020 Jun;30(7):1201-15.

147. Ballester M, Quintanilla R, Ortega FJ, Serrano JCE, Cassanyé A, Rodríguez-Palmero M, et al. Dietary intake of bioactive ingredients impacts liver and adipose tissue transcriptomes in a porcine model of prepubertal early obesity. Sci Reports 2020 101. 2020 Mar;10(1):1-14.

148. Benz JM, Tokach MD, Dritz SS, Nelssen JL, DeRouchey JM, Sulabo RC, et al. Effects of choice white grease and soybean oil on growth performance, carcass characteristics, and carcass fat quality of growing-finishing pigs. J Anim Sci. 2011;89(2).

149. Apple JK, Maxwell C V., Galloway DL, Hamilton CR, Yancey JWS. Interactive effects of dietary fat source and slaughter weight in growing-finishing swine: III. Carcass and fatty acid compositions. J Anim Sci. 2009;87(4). 